Short Communication

\title{
Effect of Water Stress on Moisture Content Distribution in Soil and Morphological Characters of Two Tomato (Lycopersicon esculentum Mill) Cultivars
}

\author{
K. Nahar ${ }^{1 *}$ and S. M. Ullah ${ }^{2}$ \\ ${ }^{1}$ Department of Environmental Science and Management, North South University, Dhaka 1229, \\ Bangladesh \\ ${ }^{2}$ Department of Soil, Water and Environment, University of Dhaka, Dhaka 1000, Bangladesh
}

Received 1 February 2011, accepted in final revised form 20 July 2011

\begin{abstract}
This study investigates the effects of water stress on moisture content distribution at different soil layers (pot) and on morphological characters of tomato plants. Three treatments of moisture level were imposed, viz, $100 \%, 70 \%$ and $40 \%$ of the field capacity. Moisture content distribution was higher at the surface and decreased with increasing stress at all growth stages. Yield and related morphological characters responded better at $70 \%$ of the field capacity compared with other treatments.
\end{abstract}

Keywords: Tomato; Water stress; Moisture content; Tomato yield; Yield component.

(c) 2011 JSR Publications. ISSN: 2070-0237 (Print); 2070-0245 (Online). All rights reserved.

doi:10.3329/jsr.v3i3.7000 J. Sci. Res. 3 (3), 677-682 (2011)

\section{Introduction}

Tomato (Lycopersicon esculentum Mill) is one of the most popular and versatile vegetable in Bangladesh and is cultivated in almost all parts of the country. It plays a vital role in providing a substantial quantity of vitamin $\mathrm{C}$ and $\mathrm{A}$ in human diet. In Bangladesh, the average yield of tomato is $7.42 \mathrm{t} / \mathrm{ha}$, which is very low compared to other tropical countries [1]. The fruits are eaten raw or cooked. It is most popular as salad in the raw state and is made into soups, juice, ketchup, pickles, sauces, conserves, puree, paste, powder and other products [2-4]. However, water plays an important role in determining the yield of tomato [5]. Water stress limits growth and yield of tomato plants. The field experience in Bangladesh shows that too much water as well as too little, both is harmful for the crop. Constant high temperature, humidity and the sensitivity of tomatoes to water stress and poor soil aeration also inhibit the development and growth of tomatoes. To breed drought tolerant cultivars, it is necessary to identify ecophysiological and morphological characters of the plants that can attain a high and stable yield under deficient soil moisture

\footnotetext{
*Corresponding author: nahar_61@yahoo.com
} 
conditions. The objectives of this study were to investigate the effect of water stress on moisture content distribution of soil and morphological characters of the plants.

\section{Materials and Methods}

Pot experiments were carried out with two varieties of Tomato in the net-house of Dhaka University to evaluate the effect of water stress on morphological parameters - growth, yield, flowering and fruiting characteristics of tomato plants and the cultivars (BR-4, BR5) were collected from Bangladesh Agriculture Research Institute (BARI) and 30 days old seedlings were transplanted in $25 \mathrm{~cm}$ height and $30 \mathrm{~cm}$ diameter clay pots.

Pots were filled with $8 \mathrm{~kg}$ silty clay loam soil which was air dried and sieved through a $2 \mathrm{~mm}$ sieve. The soil had the following general characteristics: Sand - 5.8\%, silt - $60.2 \%$, clay - 34.0\%, field capacity (FC) - 33\%, maximum water holding capacity - 46\%, hygroscopic moisture $-1.40 \%$, porosity $-49 \%$, bulk density -1.27 gIcc, particle density -

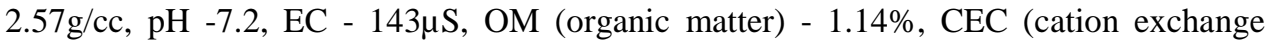
capacity) - $17.9 \mathrm{meq} / \mathrm{l00g}$ soil and $\mathrm{N}-0.06 \%$. The experiments were arranged in a completely randomized block design with three treatments and four replications.

The stress treatments were imposed at 40\% FC; $70 \%$ FC and 100\% FC (control). Moisture treatment was maintained by adding required amount of water to overcome the loss through evaporation and transpiration (measured with a weighing balance) everyday. The pots were covered with Aluminum foil to prevent evaporation loss from the soil surface.

Harvesting was started 60 days after transplanting and there were 5 harvests altogether at 5 - 7 days intervals, over one month period. At maturity yield and yield component data were recorded. Gravimetric soil moisture content was also determined from the stressed pots at $0-7,7-14$ and $14-21 \mathrm{~cm}$ depth on the last day of each vegetative and reproductive stress periods (every 15 days after transplanting).

After the last fruit harvest, plants were harvested. All the plant samples were dried in an oven at $65^{\circ} \mathrm{C}$ and dry weight of the plants were also recorded. Finally the results were statistically analyzed employing the Duncan's New Multiple Range Test (DMRT).

\section{Results}

The moisture content distribution is shown in Fig. 1. The results reveal that moisture content of soil was decreased with increasing depth at all treatment levels. The highest moisture content was found in $0-7 \mathrm{~cm}$ and the lowest in $14-21 \mathrm{~cm}$ depth at all growth stages. It was also observed that the soil in the pot became compacted differentially at different depth and made layers. Perhaps addition of water from the top of the pot has caused this differential compaction - apparently with highest compaction at the top. However, the moisture content distribution was sequential with higher in the upper layer $(0-7 \mathrm{~cm})$ followed by $7-14$ and $14-21 \mathrm{~cm}$. The findings show that, within the limit of pot depth, the moisture content distribution decreased with increasing depth. These results also confirm the findings of Rendom-Poblete [6], where moisture content distribution was 
K. Nahar and S. M. Ullah, J. Sci. Res. 3 (3), 677-682 (2011) 679

higher at the surface of soil $(0-15 \mathrm{~cm})$ and as a result root density distribution was also higher there in comparison to lower depth.
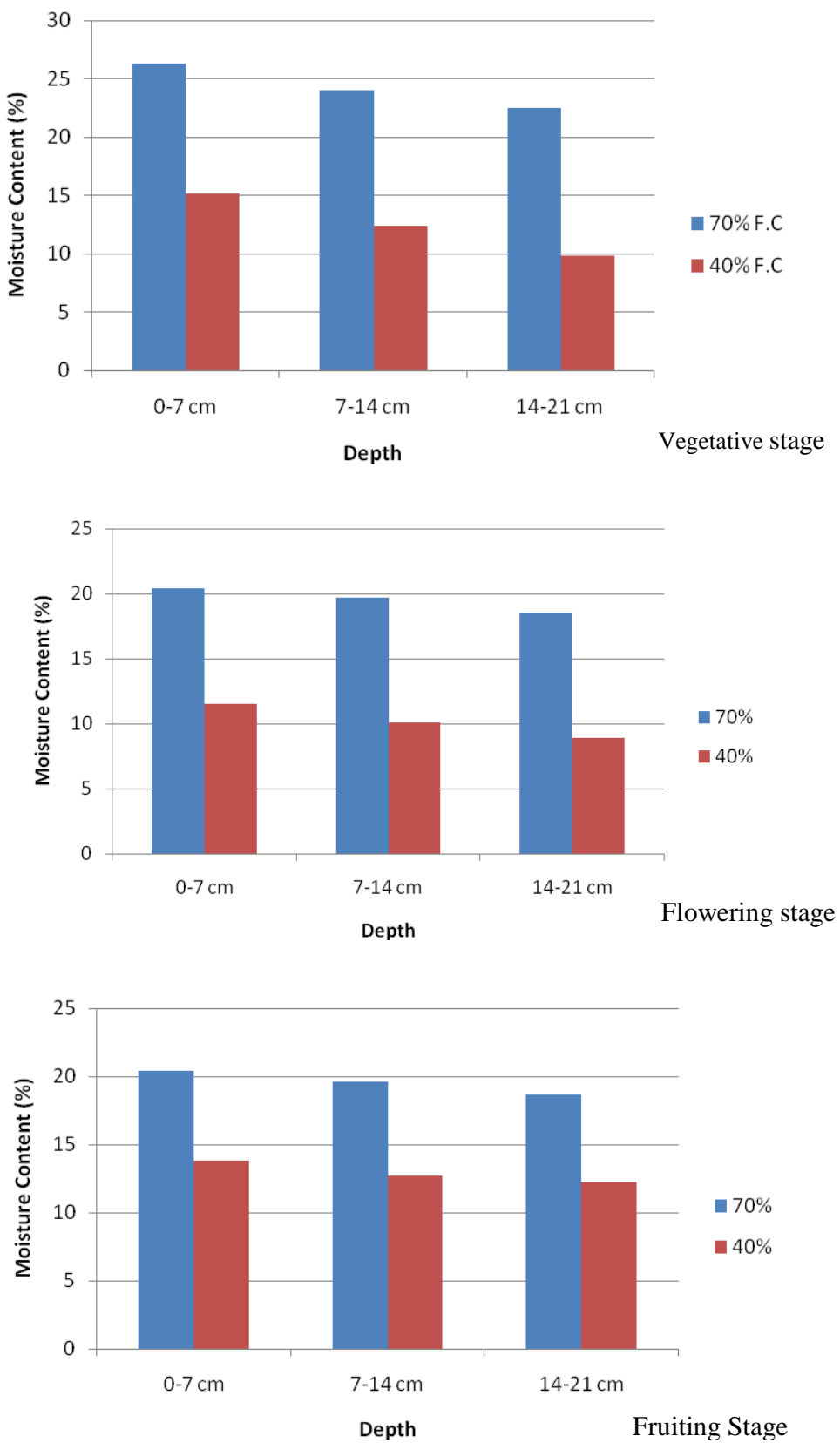

Fig. 3. Gravimetric soil moisture content at different soil depth (in pot) in response to water stress at different growth stages. 
The performances of the two varieties (BR-4 and BR-5) under stress were compared with respect to the growth, yield, plant and other horticulture characteristics. The results of yield and yield attributes in different cultivars at different water stresses were statistically evaluated and were present in Table $l$ and Table 2, respectively.

Table 1. Yield and yield attributes of tomato cultivars overall treatments.

\begin{tabular}{ccccccccccc}
\hline Cultivar & $\begin{array}{c}\text { Dry } \\
\text { matter } \\
(\mathrm{g} / \mathrm{pot})\end{array}$ & $\begin{array}{c}\text { Yield } \\
\text { (g/pot) }\end{array}$ & $\begin{array}{c}\text { Cluster } \\
\text { /plant }\end{array}$ & $\begin{array}{c}\text { Flowers/ } \\
\text { cluster }\end{array}$ & $\begin{array}{c}\text { Fruits/ } \\
\text { cluster }\end{array}$ & $\begin{array}{c}\text { Fruits/ } \\
\text { plant }\end{array}$ & $\begin{array}{c}\text { Average } \\
\text { fruit wt (g) }\end{array}$ & $\begin{array}{c}\text { Fruit stalk } \\
\text { length }(\mathrm{cm})\end{array}$ & $\begin{array}{c}\text { Fruit length } \\
(\mathrm{cm})\end{array}$ & $\begin{array}{c}\text { Fruit } \\
\text { diameter } \\
(\mathrm{cm})\end{array}$ \\
\hline BR-4 & $8.16 \mathrm{a}$ & $180.86 \mathrm{a}$ & $8.50 \mathrm{a}$ & $6.00 \mathrm{a}$ & $5.67 \mathrm{a}$ & $15.92 \mathrm{a}$ & $20.82 \mathrm{~b}$ & $2.67 \mathrm{~b}$ & $3.63 \mathrm{~b}$ & $3.47 \mathrm{a}$ \\
$\mathrm{BR}-5$ & $7.40 \mathrm{a}$ & $174.21 \mathrm{ab}$ & $8.17 \mathrm{a}$ & $5.75 \mathrm{a}$ & $4.92 \mathrm{a}$ & $12.83 \mathrm{ab}$ & $20.87 \mathrm{a}$ & $2.87 \mathrm{a}$ & $3.81 \mathrm{a}$ & $3.54 \mathrm{a}$ \\
\hline
\end{tabular}

In a column, mean values followed by same letter are not significantly different at 5\% level by DMRT.

Table 2. Effect of water stress treatment on yield and yield attributes of tomatoes overall cultivars.

\begin{tabular}{ccccccccccc}
\hline Treatment & $\begin{array}{c}\text { Dry } \\
\text { matter } \\
\text { (g/pot) }\end{array}$ & $\begin{array}{c}\text { Yield } \\
\text { (g/pot) }\end{array}$ & $\begin{array}{c}\text { Cluster } \\
\text { /plant }\end{array}$ & $\begin{array}{c}\text { Flowers } \\
\text { /cluster }\end{array}$ & $\begin{array}{c}\text { Fruits/ } \\
\text { cluster }\end{array}$ & Fruits/plant & $\begin{array}{c}\text { Average } \\
\text { fruit wt (g) }\end{array}$ & $\begin{array}{c}\text { Fruit stalk } \\
\text { length (cm) }\end{array}$ & $\begin{array}{c}\text { Fruit } \\
\text { length (cm) }\end{array}$ & $\begin{array}{l}\text { Fruit } \\
\text { diameter } \\
(\mathrm{cm})\end{array}$ \\
\hline 100\% F.C. & $5.19 \mathrm{c}$ & $136.80 \mathrm{~b}$ & $4.75 \mathrm{c}$ & $4.62 \mathrm{c}$ & $4.00 \mathrm{c}$ & $10.00 \mathrm{~b}$ & $16.27 \mathrm{c}$ & $2.37 \mathrm{c}$ & $3.34 \mathrm{~b}$ & $3.24 \mathrm{c}$ \\
$70 \%$ F.C. & $11.08 \mathrm{a}$ & $201.31 \mathrm{a}$ & $12.62 \mathrm{a}$ & $7.37 \mathrm{a}$ & $6.75 \mathrm{a}$ & $19.37 \mathrm{a}$ & $26.38 \mathrm{a}$ & $3.27 \mathrm{a}$ & $3.86 \mathrm{a}$ & $3.69 \mathrm{a}$ \\
40\% F.C. & $7.09 \mathrm{~b}$ & $194.50 \mathrm{ab}$ & $7.62 \mathrm{~b}$ & $5.62 \mathrm{~b}$ & $5.12 \mathrm{~b}$ & $13.75 \mathrm{~b}$ & $29.87 \mathrm{~b}$ & $2.67 \mathrm{~b}$ & $3.75 \mathrm{ab}$ & $3.45 \mathrm{~b}$ \\
\hline
\end{tabular}

In a column, mean values followed by same letter are not significantly different at 5\% level by DMRT.

The results in Table 1 reveal that BR-4 gave higher yield and fruits/plant but lower fruit length and fruit stalk length than those of BR-5; although there were no differences in dry matter, average fruit wt, flowers/cluster, fruits/cluster and cluster/plant. The variations in the performance were, perhaps, due to inherent individual characteristics of the different varieties.

The effect of different soil moisture regimes on yield component in tomatoes and plant dry matter reveals that there was a significant interaction effect between the varieties and soil moisture regimes. The two varieties responded better with increased number of fruits/plant and consequently yield at $70 \% \mathrm{FC}$ compared to those of $40 \% \mathrm{FC}$ and control.

The highest fruit yield was obtained from the slight stress condition followed by severe stress and control. The slight stress condition $(70 \% \mathrm{FC})$ out-yielded the other irrigation treatments significantly. Such findings demonstrate that optimum water supply for tomato is an important factor for maximizing its production. These results also confirm the findings of Lampine et al. [7], who have shown that an optimum level of water stress is required to give high fruit production in French prune.

In the present investigation, the number of fruits per plant and yield per plant indicate better partitioning ability of assimilates towards fruit development at $70 \% \mathrm{FC}$, the lowest 
yield per plant in the control treatment $(100 \% \mathrm{FC})$ and susceptibility of plants at the lower soil moisture regimes (40\%F.C.). These results agree with the findings of Singh et al. [8] and Lal et al. [9]. In dry matter production, the differences between the two cultivars were statistically insignificant. The highest dry matter production was at 70\%F.C. followed by $40 \% \mathrm{FC}$ and control. The ability of the cultivars to produce dry matter under depleted soil moisture regimes might be due to the effect of osmotic adjustment [10, 11].

The flower and fruit characteristics of tomato plants i.e. flower/cluster, fruit/cluster, cluster/plant, fruit stalk length, fruit length and diameter and average fruit weight, as affected by soil moisture stress, are presented in Table 2. Results show that all the flower and fruit characters were significantly affected by water stresses. The highest values were obtained at $70 \% \mathrm{FC}$ (slight stress) followed by severe stress (40\%FC) and control (100\%F.C.) All the parameters were significantly decreased due to severe water stress and control.

Maximum yield and yield attributes were observed at $70 \%$ of the field capacity. It attributed the highest yield (201.31g) than all other treatments. Its fruits number/plant (19.37g) was also higher than that of other treatments. The average fruit weight at $70 \%$ was $26.38 \mathrm{~g}$, which is considered a big fruit. Such results indicate that $40 \%$ and $100 \% \mathrm{FC}$ have affected greatly the fruit size which was reflected on the final plant yield.

\section{Conclusion}

From the observations it can be concluded that $70 \%$ moisture of the FC was adequate moisture supply for the investigated tomato plants and could be recommended for higher fruit yield and better fruit size. This result also confirms the findings of Sharma and Kumar [12] who observed higher yield in stressed condition compared to non-stressed one. However, soil compaction might have some role.

\section{References}

1. Year book of Meteorological Statistics Division, Govt. of Bangladesh, Dhaka (1999).

2. K. Ahmed, Phul Phal O Shak-Sabjee, $5^{\text {th }}$ edition (414 Senpara, Parbate, Mirpur, Dhaka, 1995) p. 440.

3. H. C. Thompson and W.C. Kelly, Vegetable Crops, $5^{\text {th }}$ edn. (Tata McGraw Hill, New Delhi, 1983) p. 611.

4. T. K. Bose and M. G. Som, Vegetable Crops in India, 1st edition (Naya Prokash, 206 Bidhan Sarani, Culcutta, India, 1986) p. 775.

5. G. Kalloo, In: Genetic Improvement of Vegetable Crops, G. Kallo and B. O. Bergh (ed.) (Pergamon Press, Oxford, 1993) pp. 645-666.

6. E. Rendom-Poblete, 'Effect of soil water status on yield, quality and root development of several tomato genotypes’, PhD Dissertation, University of California, Davis (1980).

7. D. Lampine, K. A. Shackel, S. M. Southwick, B. Olson, J. T. Yeager, and D. Goldhamer, J. Amer. Soc. Hort. Sci. 120 (2), 139 (1995).

8. K. Singh., M. D. Vyas, P. P. Singh, D. C. Thakre, and D. P. Neme, LENS Newsletter 15 (2), 7 (1988).

9. $\quad$ M. Lal., P. C. Gupta, and R. K. Pandey, LENS Newsletter 15 (1), 20 (1988). 
10. H. Richter and S. B. Wagner, 'Water stress resistance of photosynthesis: some aspects of osmotic relations'. In: Effect of Stress on Photosynthesis, R. Marcelle, H. Clusters and M. van Poucke (eds.) (Martinus Nijhoff, Dr W. Junk Publishers, The Hague, 1983) pp. 45-53.

11. D. J. Flower, A. U. Rani, and J. M. Peacock, Aust. J. Plant Physiol. 17 (1), 91 (1990). doi:10.1071/PP9900091

12. D. K. Sharma and A. Kumar, Indian J. Agric. Sci. 59 (5), 181 (1989). 